\title{
The dominion of Canada: A study in regional geography
}

\author{
Arthur Silva White Hon. F.R.S.G.S.
}

To cite this article: Arthur Silva White Hon. F.R.S.G.S. (1913) The dominion of Canada: A study in regional geography, Scottish Geographical Magazine, 29:11, 565-580, DOI: $10.1080 / 00369221308734112$

To link to this article: http://dx.doi.org/10.1080/00369221308734112

曲 Published online: 27 Feb 2008.

Submit your article to this journal $₫$

Џll Article views: 6

Q View related articles 5 


\title{
THE SCOTTISH
}

\section{GEOGR A P H I C A L}

\author{
MAGAZINE.
}

\section{THE DOMINION OF CANADA : A STUDY IN REGIONAI, GEOGRAPHY.}

By Arthur Silva White, Hon. F.R.S.G.S.

(With $M$ ap.)

(Continued from p. 547.)

PART II.-THE PEOPLE.

Population.

Tue following figures show the increase, except in Prince Edward Island, of population during the decade 1901-1911.'

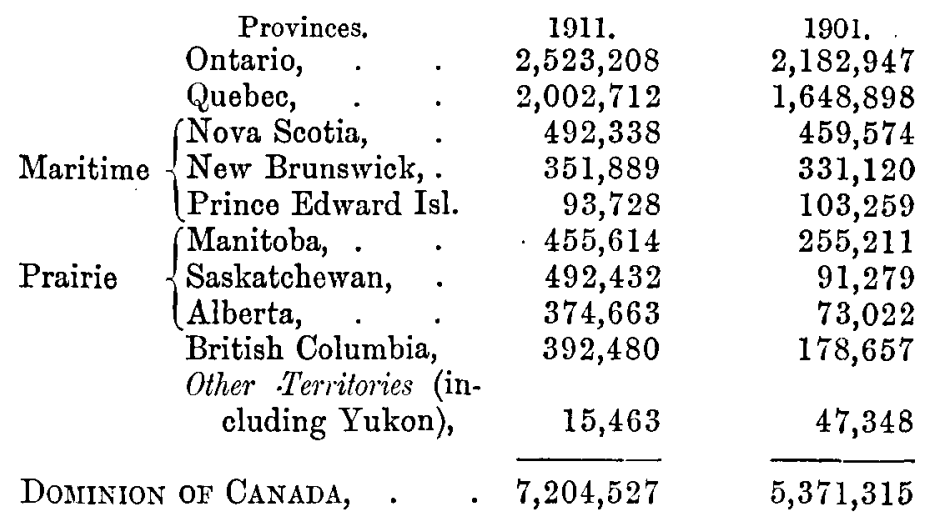

Decrease in the population of Prince Edward Island-the most densely occupied Province of the Dominion-is probably accounted for

1 Parliamentary Paper: Dominions, 1912. Ca. 6991.

VOL. XXIX. 
by migration to the Prairie and other Provinces ; nearly all are Canadaborn on the Island. In general, the movement of the population is, naturally, from the Eastern to the Western Provinces; Alberta and Saskatchewan, in particular, show the highest relative increase.

The British element predominates in all the Provinces except Quebec, which is mainly French in origin; and Protestant denominations are everywhere in a majority save in Quebec. Roman Catholics in the Dominion exceed $2 \frac{1}{4}$ millions. The proportion of foreign-born (American, Russian, German, Austro-Hungarian, Chinese, and others) is largest in the Western Provinces and in the unorganised Territories. 'In the latter, it is estimated that there is not more than one inhabitant to fifty square miles. In 1910 there were 110,597 Indians and Eskimo (in Arctic lands) representing the aboriginal population. The Athabaskan and Algonkin tribes are the most widely distributed. The Indians are grouped in reservations-as small and as wide apart as possible - and give little or no trouble. In Eastern Canada they. follow industrial pursuits, and the franchise has been extended to them.

Following is the population (1911) of the principal cities and towns :

\begin{tabular}{|c|c|c|c|c|c|}
\hline \multirow{6}{*}{$\begin{array}{l}\text { Montreal, . } \\
\text { Toronto, } \\
\text { Winnipeg, } \\
\text { Vancouver, }\end{array}$} & & & & & Inhabitants. \\
\hline & . & . & & $\cdot$ & 470,480 \\
\hline & . & . & & . & 376,240 \\
\hline & . & . & & . & 135,430 \\
\hline & & & & 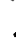 & 100,333 \\
\hline & (North and & South), & 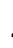 & . & 23,802 \\
\hline Victoria, & . & . & . & ${ }^{\circ}$ & 31,620 \\
\hline Ottawa, & . & . & & . & 86,340 \\
\hline Quebec, & . & . & & . & 78,190 \\
\hline
\end{tabular}

Immigration into Canada, in 1911, was very active, totalling 351,072 persons. Of these, 130,102 came from the United States, and 175,000 from the United Kingdom. English immigrants have increased by 20 per cent., and Scottish by. 30 per cent. The total increase, as compared with 1910 , was 40,000 . There was a relative increase in the number of British over American immigrants, and a relative decline in the influx from other countries. During the twelve months from April 1, 1911, to March 31,1912 , emigration to Canada was even higher : ${ }^{1}$

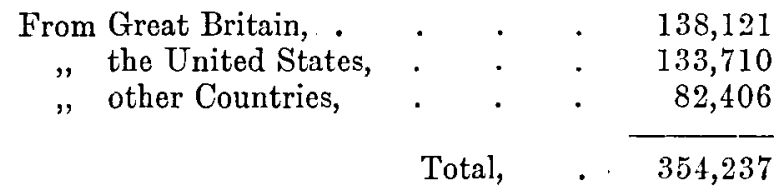

\section{Characteristics.}

The emergence of a national type out of the two good stocks on which it is founded, in Canada, has been necessarily affected by the proximity and close intercourse of the United States, no less than by

1 Statement by Mr. Buxton in the House of Commons, Oct. 21, 1912. 
the influx in large numbers of Scotsmen in Nova Scotia and of the United Empire Loyalists into the Maritime Provinces. But the blend marks off Canada, in its social and national characteristics, from the American Union, and carries on the traditions of the Mother Country, except that there is no leisured class in the Dominion.

The Americanisation of Canada, introduced through the newspaper press rather than by the flood of emigrants to the Dominion, does not appear to have affected materially the more conservative and idealistic elements of the population, based on its Northern ancestry. The born Canadian is suspicious of talkers and hustlers, and his farm is more his home than his place of business: he is not for ever on the tiptoe of expectation. But his ignorance of the Mother Country, in its modern aspects, is great, though not so great as in the reverse direction: in both cases, ideas of each other are based on information some generations out of date.

\section{Constitution and Governalent. ${ }^{1}$}

Canada is a Self-Governing Dominion of the British Empire. The Governor-General is appointed by the King. 'The Executive Government is vested in the Crown, and is exercised by the Governor-General, assisted by a Privy Council chosen and summoned by himself. The Cabinet is a Committee of the Privy Council, consisting at present of fifteen of the principal members of the Dominion Government, or Ministers.

Supreme legislative power is vested in a Parliament consisting of the King, a Senate, and a House of Commons. The Gorernor-General in Council appoints Lieutenant-Governors for the Provinces, and, in certain circumstances, removes them; appoints also officers for the effectual execution of the Constitution. Each Province has a Legislative Assembly ; in Quebec and Nova Scotia there is also a Legislative Council, forming a Second Chamber. Unlike the Constitution of the United States, that of Canada vests the Dominion Parliament with exclusive legislative power in all matters except those specifically delegated by the Constitution to the Provincial Legislatures, which on their side possess the power of altering their own Constitutions. Territory not comprised within any Province is governed by a Commissioner and a Council of four appointed by the Governor-General in Council.

The Judges are appointed by the Governor-General in the Superior, District, and County Courts throughout the Dominion, except in the Probate Courts of Nova Scotia and New, Brunswick. His Excellency has the right of pardon and reprieve.

As regards bills passed by the Provincial Legislatures, the GovernorGeneral is in the same position as the King in Council for Self-Governing Colonies. His salary ( $£ 10,000$ a year) is paid out of the Consolidated Revenue Fund of Canada.

1 Colonial Office List, 1912; Analysis of the System of Government throughout the British Empire (Anon.), p. 79. 
The Lieutenant-Governor of a Province is assisted by an Executive Council composed usually of the chief officials who possess the confidence of the Provincial Assembly. Manhood Suffrage prevails to a very considerable extent.

The Central Government, which assumed the Provincial Debts existing at the time of the Federal Union, pays to each Province an annual allowance for purposes of government and an annual subsidy, per capita. Divergence of interests-inevitable in a young and rapidly expanding Colony-there has been in the past between the Central and Provincial administrations; but a tendency towards consolidation of interests, rather than the exercise of restraint by the Central Government, is markedly supporting a true national and imperial policy, and is giving effect to that material unity which Canada has sought to attain, in all earnestness and sincerity.

Local self-government in municipal affairs is general, and it has been developed to the fullest extent.

Ottawa is the seat of the Dominion Government, which is representcd in the United Kingdom by a High Commissioner, resident in London.

\section{Atiantic Provinces.}

The United Empire Loyalists and emigrants from the Highlands of Scotland, who found new homes in a New Scotland, encountered familiar surroundings in the bold coastlands of Nova Scotia; and the Nova Scotian. Assembly is the prototype of our Colonial Parliaments. Nova Scotiaitself all but an island-together with Cape Breton and Prince Edward Islands, reproduce many of the physical features of the British Isles, and, with New Brunswick, represent a stage of transition from oceanic to continental conditions. But the earliest colonists were French, who called the country L'Acadie.

Nova Srotia. - The capital city, Halifax, with its magnificent harbour on the Atlantic coast, was-and is, though not actively-an important. naval base for the British fleet. Since the Boer war, Halifax has been taken over, for naval purposes, by the Dominion Government. It is a thriving seaport, open, unlike the ports of the St. Lawrence, to the world's shipping all the year round; and, like the port of London, it. serves as a distributing centre-at least in the winter months-for Canadian produce and foreign imports. The city of Halifax has a University (Dalhousie), and is the centre of educational as well as of industrial life. West of Halifax county, on the south coast, is Lunenburg county, peopled by the descendants of German settlers who emigrated from Hanover in 1751 .

Although agriculture and mixed farming-chiefly fruit-growing and dairy farming - are the principal occupations of the people, the fisheries of Nova Scotia give employment to about 14,000 men. Thousands of men, too, are employed during the winter in the forests, which, though greatly thinned out, yield good supplies of pulp-wood. The "marsh" lands, formed by the phenomenally high tides of the Bay of Fundy, are of peculiar value to the dairy farmer, and the land reclaimed is of inex- 
haustible fertility. We have referred already to the mining industry, which gives employment to a considerable section of the population.

The vast majority of the people are of British stock.

Pirince Edtard Island, the smallest Province of the Dominion, is also the most densely populated : 47 inhabitants to the square mile, the mean for the whole Dominion being 1.9. Scotsmen predominate, followed by English and Irish, with an increasing number of French Canadians. Here the forest has been cleared to make room for farms, which cover practically the whole Island: "the million-acre farm," it is called. Charlottetown-the only city in the Island-is well situated on a bay in the middle of the south shore.

A considerable portion of the population are employed in industrial pursuits, but the bulk are farmers. The Provincial Government, as in other Provinces, for many years has carried on a stock farm, and has imported also a number of pure-bred stock, besides establishing model orchards; while the farmers themselves have organised co-operative agricultural associations. Many of the smaller farmers engage also in the "fisheries," chiefly lobsters and oysters.

Education is free; and for higher education the Prince of Wales College is maintained at Charlottetown. There are many churches on the Island, the majority being Protestant; and there is also a strong Roman Catholic community. Social life, to a large extent, centres round the churches.

New Brunswick, though nearly as large as Scotland, has relatively only one-tenth of the population. Originally the most densely afforested of the Maritime Provinces, the coastal lands have been cleared and deep inroads made in the central parts for farming. Most of the pine timber has gone, but there remain spruce and a great variety of hardwood, the products of which are exported in large quantities, besides being sent to other parts of Canada and to the United States.

The forest and the fisheries, to a certain extent, have distracted attention from farming; but agriculture flourishes, not only in the broad valleys and on the undulating plain, but along the banks of many streams running through parts of the country still devoted chiefly to lumbering. The county of Northumberland, in the north-east, contains the largest area of wild land. In the valley of the St. John River-on which Fredericton, the capital, is situated-and in the valley of the Miramichi River-which divides the county of Northumberland-there are good farm lands and many farmers. The establishment of cheese and butter factories all over the country has raised this branch of agriculture to the first place.

The Provincial Government imports cattle, sheep, and pigs of the best breeds, and sells these by auction at prices below cost, on condition that. the animals be kept in the Province; the farmers also co-operate among themselves. A dairy school is maintained at Sussex.

The bulk of the population-scattered over the country districts-are of British stock, descended mostly from the United Empire Loyalists. There are three universities in the Province, one being a State institution at the capital. St. John, at the mouth of the river of that name is 
a much larger town than Fredericton. It is a seaport, railway terminus, and manufacturing centre.

\section{River and Lake Provinces. ${ }^{1}$}

The settlement and development of Quebec and Ontario Provinces have been determined largely by the well-defined geographical conditions that make of this region one of the most favoured in America for economic growth. The extensive system of waterways, great variety and wealth of natural resources, and a people welded together out of the descendants of two great colonising powers, combine to give the River and Lake Provinces of Canada advantages of unique value. In Ontario the English, and in Quebec the French elements predominate; but in the Dominion Government at Ottawa harmony and identity of interests may be said to prevail over local and racial prejudice. The absorption of New France into the body politic of our premier Colony is one of the most notable achievements of British Colonial polity, and a favourable augury for the experiment now being worked out in South Africa between British and Dutch elements. Even the bi-lingual impediment, which in South Africa retards complete fusion in the present generation; has been overcome to a great extent in Canada by the logic of events that could not be denied a prosperous people working towards a common end-the unity and consolidation of the Dominion.

Quebec.--In the Province of Quebec many of the customs, institutions, and picturesque trappings of Old France are enshrined and displayed by a people who, while cherishing their birthright as the first conquerors and settlers, are as loyal to the British connection as any other in the Empire. When the British Colonists further south rebelled against the rule of King George, the French-Canadians refused to join them, and themselves helped the British troops to repel the American invasion in 1775, and again in 1812. The subsequent revolt of the Colonists, both British and French, were ebullitions of patriotism which won freedom for their country by the destruction of the feudal system.

English-speaking people outside the city of Montreal are found chiefly in the southern section, bordering the United States. In the rest of the settled districts of the Province they are scattered very thinly among the French-Canadians. The French spoken is no patois, but the language of Middle France-except in accent-in which some English words and corruptions are traceable.

Like the French in Europe, the French-Canadian is light-hearted, hospitable, industrious and thrifty; and he is fond of politics. Almost all are Roman Catholic, and devoted to the Church, to which they pay a percent-

1 The Dominion Governnent have come to a decision as to the settlement of the ques: tion of the extension of the boundaries of Ontario and Quebec. Quebec obtains the territory known as Ungava, and Ontario that part of the North-West Territories which lies south of a line drawn approximately from the north-east corner of Manitoba to a point fifty miles south-east of Port Nelson, the remainder of the country south of the 60th parallel being allotted to Manitoba. The Provincial Legislatures concerned in this matter have accorded their assent,-Dominions Report, No. 12, for $1911-12$ (Cd. 6091), page 64: 
age of their produce for maintenance charges. Although about, or nearly, half a million of the people live in Montreal - the commercial capital of the Province-almost two-thirds of the entire population are found in the country districts, where the farmers nearly all own their own land and homesteads. The distribution of the population coincides mainly with the valleys of the St. Lawrence and its tributary, the Ottawa River, which it shares with Ontario; and flourishing homesteads are found in the south, right up to the United States frontier.

Quebec, the capital city, beautifully situated on the St. Lawrence, and most picturesque in itself, has extensive docks and important manufacturing industries. It is the seat of Provincial legislation and administration, and has one of the oldest universities in Canada, named after the first bishop, Laval.

Montreal-the Liverpool of Canada-with rapidly developing interests in shipping and manufactures, is a busy centre in which a large and influential section of the community is English. The city lies a thousand miles inland from the open Atlantic, but the St. Lawrence River is here a mile and a half wide. It is the headquarters of the Canadian Pacific Railway, which crosses Canada to the Pacific Coast, and also of the Grand Trunk Railway; other lines radiate in all directions, linking up this important distributing centre with the American Continent.

Montreal is rich in churches and cathedrals-so rich, that Mark Twain once said he could not throw a stone without breaking a church window. The largest are the Roman Catholic cathedral, built on the plan of St..Peter's at Rome, and the ancient parish church. Christ Church is the Anglican cathedral.

The educational system of the Province is adapted to the requirements of the people. Roman Catholic institutions are both many and large. The Church of England maintains a university college at Lennoxville. As an educational centre Montreal ranks high, its McGill University being comparable to Harvard and Yale in the United States; and there is a famous agricultural college, created by Sir William Macdonald, at St. Anne's.

Other urban centres are the old French settlement of Three Rivers, between Montreal and Quebec; the city of Hull on the Ottawa River, and the industrial town of Valleyfield, with its cotton and paper mills. Sherbrooke is the capital city of the eastern townships, charmingly situated on the banks of the St. Francis River. St. Hyacinthe is a centre of the leather industry. Northwards of the St. Lawrence, a manufacturing centre is growing up on the banks of the St. Maurice River, where the Shawinigan Falls are utilised as a power station.

When winter comes, the lumbermen invade the densely wooded area lying north of the cultivated valleys of the St. Lawrence and Ottawa Rivers. Much of the land being of good quality, the farmer is making inroads into the forest; and it is also a favoured region for sport and residential estates.

Ontario.-The leading Province of the Dominion was discovered and opened up by a band of famous explorers-Champlain, founder of Canada; Joliet, discoverer of the Mississippi; and La Salle, who navi- 
gated that mighty river to its mouth in the Gulf of Mexico-and missionaries who, together with the intrepid "runners of the wood," braved perils by land and water in untracked Ontario, the record of which is among the most romantic in pioneer literature. But the solid and enduring foundations of the structure we know to-day were built up by the Loyalists and others of British stock, as in the Maritime Provinces. Ottawa, the seat of the Dominion Government, is situated in Ontario, on the right bank of the Ottawa River, which flows eastwards for one hundred miles to its union with the St. Lawrence near Montreal. Ottawa is very much smaller than Toronto.

Toronto, on the north-west shore of Lake Ontario, is second only to Montreal in population and importance. Nearly half of the Canadian banks have their headquarters in this city, in which there are numerous factories, department stores, and wholesale warehouses. Its university is the largest in the Dominion; and it is perhaps the leading centre in Canada for the newspaper press. Toronto is the political capital of the Provincial Government.

Ontario leads the way in manufacturing activity. In towns too numerous to mention, mills and factories are busy. Iron and its products, from tin-tacks to locomotives - and, in particular, agricultural machinery - support a large and increasing industry. In the southwestern peninsula-surrounded by Lakes Huron, Erie, and Ontariowhich is covered by a relatively dense population, this activity is at its highest. The great coalfields of Pennsylvania lie on the other side of Lake Erie, and Niagara Falls are near by to supply power. A great iron and steel industry is being created at Sault St. Marie, where the waters of Lake Superior spill into Lake Huron.

The Provincial Government has set aside some ten million acres of wild land in northern and western Ontario as a forest reserve; and in the peninsula the Algonkin National Park provides a game and fish sanctuary. Allusion has been made already to the forest and mineral resources of Ontario. Neither these nor manufactures constitute the principal wealth of the Province. Ontario is essentially a farmer's country. The whole of the peninsula, between the Ottawa River and Detroit River, at the United States frontier, is an agricultural country. Wheat and oats are raised in very large quantities, as well as maize, barley, peas, roots and hay; but a large proportion of these field-crops are consumed as food for the live stock used in dairying. Ontario makes more cheese than any other Province. Fruit-growing, too, especially in the south, round Iake Erie, is a profitable industry: in all this favoured district of orchard land the peach and vine grow to perfection. At Guelph there is a well-known agricultural college; and the Federal Government maintains experimental farms and orchards in many parts, including the central one at Ottawa, at which emigrants and others receive training.

In the eastern counties, as might be expected, French-Canadians have settled in considerable numbers; but the Province as a whole is essentially British in settlement. In the county of Waterloo there is a strong German contingent; and Negroes, Indians, and half-breeds aro scattered throughout. 
There are about six thousand free public schools, many High Schools and Collegiate Institutes, besides the Universities of Toronto and Ottawa. The Province is mainly Protestant; but, although denominational grouping prevails, as elsewhere in Eastern Canada, no Church is privileged.

\section{InLAND Provinces.}

Manitoba and the great North-West is indissolubly connected with the name of "The Company "- the famous Hudson's Bay Company, with Prince Rupert at its head, which received from Charles the Second a grant of some two and a half million square miles of territory round Hudson Bay at an annual rental of " 2 elks and 2 black beavers." Its fortitied posts - chief of which was Fort Garry, south of Lake Winnipegbecame trading centres, to which the Indian and other trappers brought their pelts; and its treatment of the natives was proverbially good. One of the first acts of the Federal Government was to buy out the monopoly of the Company ; and, when settlers began to come in to the "NorthWest," tho Red River district was organised and Fort Garry became Winnipeg by name.

The phenomenal growth of this Prairie City and the rapid development of the vast area of wheat-lands to the west are among the leading achievements in the settlement of British North America. Other branches of agriculture have proved no less successful; and dairy farming has made great progress. The Dominion Government maintains an experimental farm at Brandon.

About eighty-five per cent. of Manitobans are English-speaking; and by far the greater number of these were born either in the Province itself or are immigrants from Ontario. Waves of immigration have swept in from south-eastern and north-western Europe, leaving settlers from many lands. While a large number of the Roman Catholics are the descendants of the old French fur-traders, Presbyterians predominate.

Elementary education is supported out of public funds. The Province does not lack High Schools and Colleges. At Winnipeg the University of Manitoba is well equipped.

Saskatchezan.-The physical features of Manitoba-a gently rolling prairie, mostly bare of trees-are continued in the southern borders of the newer Province of Saskatchewan, but the further one proceeds west the drier the country becomes. This dry patch carries good wheatlands in the south-east and south-west, with an agricultural and stockranching population that is rapidly increasing. In the well-watered park-lands to the north, mixed and dairy farming have better opportunities.

The people are of various origin, having come in with a vast stream of migration that has increased the population of Saskatchewan and Alberta over five times within the last decade. Most of the people are English-spealing immigrants from other parts of Canada, the Home Country, and the United States; while many of the emigrants from the States are Old-Canadians. Galicians and Scandinavians are - numerous. 
Regina, the Provincial capital, is the headquarters of the famous North-West Mounted Police. It has a university college.

Alberta.-The twin-province of Alberta resembles Saskatchewan in its population and resources. The vast high-plateau in the south, which formerly was the home of the cattle-king and the cowboy, is, in spite of a light rainfall, suitable for autumn-sown wheat; and land is being brought under cultivation. Irrigation has been introduced in southern Alberta, where the land slopes down from the mountains; and here beets are grown for sugar. Cattle-ranching still flourishes in among the foothills of the Rockies and elsewhere, and horse-ranching supplies local requirements for the farm.

Railways are opening up the country rapidly, and settlers follow in their track. In the northern half of the Province, beyond the reach of the railway at present, the well-watered forest-lands are the home of furtraders, who bring in their skins to the Hudson's Bay Company's stores at Edmonton.

The growth of Edmonton, the Provincial capital, has been very rapid within the last decade: it is now a city with fine public buildings and a university. Edmonton, too, like Calgary - which rivals it-is an important railway centre.

\section{Pacific Protince.}

The discovery of gold, in 1858, let in a rush of population. Thirty. three thousand men from the Californian mining camps came up in one summer to prospect the valley of the Fraser River and its tributaries; but they disappeared as suddenly, with disappointed hopes. This influx; however, led to the organisation of the Province. Gold-mining continued, until the discovery of rich deposits in the mountainous Caribou district brought on another invasion of gold-seekers from California, Australia, and other parts.

British Columbia, on joining the Federation, stipulated for a transcontinental railway to link up its rich mineral lands with the Eastern Provinces. Thus, the Canadian Pacific Railway was carried to, and created, Vancouver - now the largest city of the Province and the fourth largest of the Dominion. Victoria, the Provincial capital, stands at the southern end of Vancouver Island. The railway terminus and seaport at Prince Rupert are, in like manner, the creation of the Grand Trunk Pacific Railway.

Chinese and Japanese labour was drawn upon largely in the early days of settlement, with a result that their exclusion or strict limitation nowadays are topics that closely concern the Provincial Legislature, which is anxious to keep British Columbia essentially a white man's country: The bulk of the population is British in origin-mainly by direct emigration - and includes a large contingent of Canadians from other parts of the Dominion. The influx from the United States has been very con: siderable, and Scandinavians also are numerous. Protestant denomina. tions predominate. 


\section{The Territories.}

East of the Yukon, to which reference has been made, lies Mackenzie Territory, which comes under the authority of the Crown exercised by the Royal North-West Mounted Police. Its northern shore, washed by the Arctic Ocean, is visited by these smart troopers and by whalers from Bering Sea. Both in Mackenzie and in Keewatin, which includes the western shore of Hudson Bay, there are some missionaries and fur-traders, but otherwise no white population. Ungava, too-between the eastern shore of Hudson Bay and Labrador Coast-is little visited.

There are over one hundred thousand Indians and half-breeds scattered over the Dominion, and their numbers are not increasing. A majority of these are found in Manitoba and the North. West Territories; but over twenty thousand remain in each of the other regional areas surveyed by us: British Columbia, Ontario, Quebec, and the Maritime Provinces. Dr. Bryce, of Winnipeg, classifies the aborigines under (1) Algonkin, (2) Dakotas, or Sioux, (3) Chippewayans, or Athabaskans, (4) Indians of British Columbia (Iroquois in the north, Salish and others in the south), and (5) Eskimo. The great Algonkin family is the connecting link between East and West; but the origin of by far the most remarkable of these tribes, the Iroquois, is lost in hopeless obscurity. The great reformer and lawgiver of the Iroquois, Hiawatha, who rose to power in the middle of the fifteenth century, constructed a federal system which revived the Five Nations and survives to this day, although his scheme for a confederation of all the tribes fell short of fruition.

\section{Trade and Commerce.}

An appreciation of Canadian literature and art should, properly, precede the consideration of trade and commerce; but exigencies of space preclude more than this passing reference. ${ }^{1}$ Of trade and commerce, too, to which incidental references have been made already, little need be said in this place. The oversea trade of the Dominion is expanding, the gross figures for the year 1912 exceeding, for the first time, 200 million pounds sterling. In 1912-13 the proportion of imports from the United Kingdom to total imports was 20.3 per cent., whereas that of the United States was 65.5 per cent.

The economic development of Canada is indicated by the stages through which she has passed in her experimental search for a fiscal policy. Under the French régime she was ground down by monopolies set up and supported by a ruthless administration of military autocrats. "Let us beware," wrote Montcalm, "how we allow the establishment of manufactures in Canada; she would become proud and mutinous like the English. ... So long as France is a nursery to Canada, let not the Canadians be allowed to trade, but kept to their wandering, laborious life with the savages, and to their military exercises." 2 . Cession of the country to

1 Cf. Canadian Life in Town and Country, by H. J. Morgan and L. J. Burpee (p. 192); and British America, vol. iii. of the "British Empire Series,". in which Sir J. G. Bourinot gives a short review of Canadian literature.

2 Quoted in Canadian Life, op. cit. (p. 63). 
England brought some relief; but the prohibition of foreign trade was maintained. The Navigation Laws restricted external commerce to the Mother Country and the Thirteen Colonies, and thus set up a preferential policy which was met in England by substantial reductions in the tariff. But this growing trade collapsed on the abolition of the Corn Laws. It revived, however, between 1855 and 1866, when a Reciprocity Treaty was in force between Canada and the United States. The treaty was abrogated by the Republic, but not before Canadians had sown their wild oats and settled down to business: it helped materially to break down antagonistic interests and hostile tariffs between Province and Province, leading eventually to Federation and the pooling of economic interests.

This was not accomplished without much friction between the Conservative and Liberal parties, the final issue of which was fought out at the General Election of 1911, when Reciprocity with the United States was the question at issue. When Parliament was dissolved, the Liberals held 133 seats and the Conservatives held 88 seats. When again it met, the Conservatives held 131 seats and the Liberals were reduced to 87 seats : a complete landslide, which destroyed the Reciprocity Agreement by which Canada would have become "an adjunct" of the Republic, and definitely confirmed the adherence of Canada to "the old house." While controlling her own fiscal policy, Canada, through the Underwood Tariff, will derive nearly all the benefits suggested by the Reciprocity Agreement.

The Customs tariff of Canada is protective, but preferential towards the United Kingdom and most of the British Colonies. It is urged by Tariff reformers in the United Kingdom that Reciprocity with Canada and the other Dominions should replace-where these exist-Free Trade restrictions at present prevailing.

The banking system of Canada, though marked by efficient Government control, is very accommodating, the banks being allowed to increase their note circulation when the needs of commerce demand it: this is important for Canada, whose trade expands and contracts with the seasons. The value of English money is fixed by law, a sovereign being worth $4.86 \frac{2}{3}$ dollars, and a crown being worth $1 \cdot 2$ dollars.

A branch of the Royal Mint is established in Ottawa : sovereigns and half-sovereigns coined there are legal tender in every country under the British flag. Only five coins are used in Canada : the 50-cent piece (half-dollar), the 25-cent piece (quarter-dollar), corresponding to the shilling, the 10 - and 5 -cent pieces, and the copper cent, about equal to a halfpenny. Paper money, issued by the Government and the banks, is used universally for all sums from one dollar upwards.

Consular Service.-The British Consular Service is open to Canada and the other Dominions. The Canadian Trade Department is furnished by our Foreign Office with Consular Reports, as required; and any Canadian firm may apply for information direct to British Consuls, who will report thereon. Canadian Trade Commissioners (resident in Europe, etc.) are at liberty to apply to British Consuls for advice and assistance. Members of the Canadian Commercial Service, who may be accommodated with office-room-if available-in British Consulates, are eligible for the 
Illustrating Mr Silva White's Article.

CANADA-DENSITY OF POPULATION CANADA DENSTO

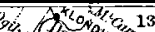

125

120.120

110

125

(os

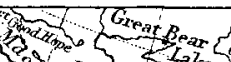

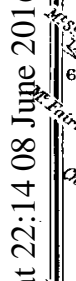
45 (3)

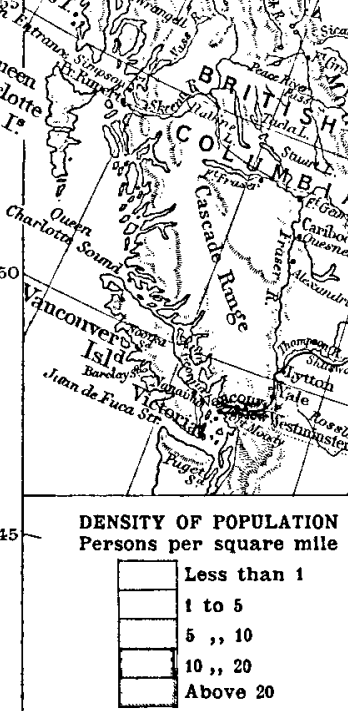

$\square$ Country settled since 1901

$$
120
$$


British Commercial Service, under an arrangement that has been come to between our Foreign Secretary and the Canadian Minister of Trade and Commerce. ${ }^{1}$

\section{Exteiral Relations.}

We now have reached a stage at which we can report progress. We have seen the bold Elizabethan navigators and adventurers opening up the horizon of the New World. We have followed in the path of conquest and empire, and we have witnessed the flow of settle. ment from east to west across British North America-deepest in the Eastern Provinces and thinning out to a few rivulets passing through the Rockies to the Pacific Province. All that we have experienced, so far, has been enacted well within the North Temperate zone-dipping, indeed, into the Arctic-under conditions not dissimilar, save in degree, to Northern Europe ; but enacted in so vast a theatre, that in many parts the human element is all but lost to view. Finally, we have to realise that in the people of Canada we find a definite grouping, but not too disproportionate a share in numbers, ${ }^{2}$ between the British and French elements of national life, in which English ideals prevail so strenuously that, like Aaron's rod, all other elements are thereby absorbed. It is an English country from end to end, save in Quebec, which, though not imperial-minded, is thoroughly loyal and constant to the British causewhich, indeed, is their cause, inherited through their Norman ancestry. What Canada wants is men and money-more men and more capitalto develop her boundless resources and to foster her national life. Sir Wilfrid Laurier, the eminent French-Canadian, characterised Canada as "the gem of the British Crown." Rather, we would regard the premier Colony of the Empire as Britain beyond the Inland Seas, to whom is entrusted the task of carrying on English traditions and European culture. The women of Canada, too, are more identified with industrial and social progress than are their cousins in the Home Country. They have inspired many of the most vital social reforms and educational advances. Woman, in Canada, is the bulwark of religion, and reigns supreme in the home, upon which the whole social structure rests-and this, more particularly, is the case in the Province of Quebec.

In our view, Canada is a country which the Dominion Government holds-as in the case of the other Dominion Governments-in trust for the Empire: it is not exclusively a country to be used for its own purposes by the favoured few who have their homes there. It has duties to the Empire, as such-duties of British citizenship, so to speak-and these constitute a redemption of the great moral debt which was built up overseas by the blood and treasure of the Motherland.

Defence.-The Imperial garrisons at Halifax and Esquimault were

1 Statement by Mr. Acklanil in the House of Commons, November 26, 1912.

2 In 1911, English-speaking persons numbered 3,721,944; and French-speaking, 1,619,371. Moreover, French-Canadians clain a million compatriots in the neighbouring Republic, some of whom are returning to the home of their ancestors. Direct emigration from France has ceased long ago. 
withdrawn, owing to the patriotic offer of Canada during the Boer War to maintain these prime naval bases at her own expense. The control of Admiralty property at these stations was handed over finally in 1910 to the Dominion Government, on the understanding that H.M.'s ships of war shall be given facilities, and that the naval dockyards be kept up.

In regard to naval defence, towards which Canada makes no direct contribution, the proposal of the Borden ministry to provide for the construction-as an emergency measure-of three battleships or battle cruisers of the latest type, at a cost of thirty-five million dollars, has not yet been sanctioned by the Dominion Parliament. In the Home Country, Canada is entitled to representation at special meetings of the Committee of Imperial Defence, together. with the other Dominions, who have accepted in principle the proposal-brought forward at the Imperial Conference of 1911 - that a Defence Committee be established in each Dominion.

The number of men who were trained in the Militia in 1910-11 was 39,512 . A scheme has been drawn up whereby the organisation of the Militia in Eastern Canada will be the same in peace as it would be in war. In March 1911 there were 263 gazetted Cadet Corps, the success of which movement has an important bearing on the efficiency of the Militia; which at present is crippled by lack of qualified officers and N.C.O.'s, as well as by the restricted term (twelve to sixteen days) of annual training. The general plan of the Department of Militia and Defence of the Dominion is to organise 100,000 men in first line and 100,000 in second line. The first line, or Active Militia, is making fair progress; the second, or Reserve Militia, is unorganised.

\section{Comingications.}

Internal.-The Canadian Pacific Railway, 2906 miles in length, traversing the continent, linking up centres of settlement and penetrating new fields for conquest, always has stood in the van of progress. Its work and its policy have been broadly Imperial, no less than vital to the Dominion in its early days of development. Other transcontinental railways have come into existence; and two of these will reach the Pacific by 1914, when the Panama Canal will be open for traffic. The two new lines are the National Transcontinental, or Grand Trunk Pacific, Railway to Prince Rupert, and the Canadian Northern Railway to Vancouver. The Mackenzie and Mann system also is constructing transcontinental connections.

A network of recently constructed railways criss-crosses the Prairie Provinces in their southern parts; and the River and Lake Provinces are fully served by railroads as well as by waterways. The same may be said of the Maritime Provinces, which also have the Intercolonial Railway.

In June, 1911, the railway mileage in operation throughout Canada was 25,400 miles, or over 2000 miles more than in the United Kingdom in the same year; and another 1600 miles of railway were in partial operation.

The Federal Government have undertaken, by 1914, to construct a railway to Hudson Bay - to the tide-water terminus at Port Nelson-in 
connection with which it is contemplated to run a line of boats across James Bay to the Nottaway River, where a railway line could be carried to Labrador or Quebec. The road starts from the crossing of the Saskatchewan River at the Pas Mission. The distance from the wheat-fields to Hudson Bay is practically the same as to Fort William, at the head of Lake Superior; likewise, the ocean voyage from the Bay, under favourable conditions, equals approximately that from the St. Lawrence during the period of safe navigation: thus, under favourable conditions, the economic saving would be equivalent to the cost of transportation from Fort William to Montreal. The period of safe navigation is reckoned at four to five months (July to November) for Hudson Bay, and a month less for Hudson Strait, where ice-breakers could be used to keep open the fairway and to signal ice-conditions by radio-telegraphy.

External.-The increase in the popularity of the St. Lawrence route, for immigrants and tourists, is indicated by the following figures of traffic by the principal trans-Atlantic lines operating direct between British and Canadian ports during 1911: ${ }^{1}$

$\begin{array}{lcccc}\text { Steamship Line. } & & \text { Westbound. } & \text { Eastbound. } & \text { Total. } \\ \text { Allan, } & \text {. } & 61,709 & 19,330 & 81,039 \\ \text { Canadian Pacific Railway, } & 40,200 & 18,750 & 58,950 \\ \text { White Star Dominion, } & \text {. } & 29,162 & 12,985 & 42,147 \\ \text { Royal (Bristol), . } & \text {. } & 13,204 & 6,351 & 19,555 \\ \text { Donaldson, - . } & \text {. } & 9,911 & 1,771 & 11,682 \\ \text { Cunard, . } & \text {. } & 5,972 & 1,080 & 7,052\end{array}$

The contract for the conveyance of the direct weekly mail (LiverpoolHalifax in the winter months, Liverpool-Quebec in the summer) is held by the Allan Line. Supplemental routes also are used.

The British Government pays $£ 20,000$, and the Dominion Government pays $£ 25,000$, per annum, to the Canadian Pacific Steamship Company for the trans-Pacific mail service between Vancouver and Hong.Kong, via Yokohama: this is the Empress Line, with two 18-knot steamships, of 15,000 tons gross, and six others. The service is three-weekly from each terminal port; and the contract time, from Liverpool to Hong-Kong, is 818 hours via Quebec, and 853 hours via St. John, N.B. In 1911 the Dominion Government contracted afresh with the Union Steamship. Company of New Zealand for a five years' service, with monthly sailings. Other mail contracts include Lines to Havre, South Africa, Central American and Mexican ports. The Holt Line (Liverpool) operates to Vancouver via the Suez Canal and Asiatic ports.

The Great Lakes are well lighted; and cargo vessels from Lake ports reach the Atlantic without breaking bulk. In 1910 over 36,000 vessels, aggregating nearly 43 million tons, passed through the Canadian canals. Freights were chiefly in grain, iron ore, timber and coal; and the preponderance of traffic is from west to east. But nearly 80 per cent. of this traffic is American. A comprehensive scheme for the improvement of the navigation on the Great Lakes and the Welland and St. Lawrence canals is in course of construction. 
Cables.-There are thirteen cables between the United Kingdom and Canada, all of which are under American administration. The only completely British-owned cable is from Halifax to the West Indies, via Bermuda. It is, however, proposed-as complementary to the All-British Pacific Link - to lay an Atlantic Imperial cable from Blacksod Bay, on the west coast of Ireland, to Halifax.

Improved steamship and cable services, in support of the Dominion Government's trade agreements with the British West Indies, have now been arranged.

Ralio-telegraph, or "wireless," stations, open to ship and shore communications, are established along the Atlantic and Pacific coasts, on the St. Lawrence, and round the shores of the Great Lakes. At Glace Bay (Cape Breton Is.) there is a high-power public service station, for transAtlantic messages.

\section{ITALIAN EMIGRATION TO SCOTLAND.}

\section{By RalPH Richardson, F.R.S.E.}

AN Italian visiting Scotland must be struck with the fact that, go where he will, he will almost certainly find a compatriot engaged in business. There is scarcely a village in Scotland without its "Italian Ice Cream" shop, a gaily decorated place of business, with the Italian National flag painted outside, plenty of mirrors inside, and, to Scotsmen, a strange foreign name on its signboard. At one time the Italian emigration to Scotland took the form of men selling stucco casts of figures from the antique, often of considerable beauty ; at another time, Italians were, and still are sometimes, conspicuous as organ-grinders or travelling musicians. Now, however, Italian emigration has followed a more important and more lucrative channel, and we have throughout Scotland Italians occupying shops for the sale of ice-cream, confectionery, and other refreshments, taking part in Scottish trades and hotels, and becoming regular, resident, Scottish citizens.

One would imagine that Italians suffering from poverty would hesitate about a voyage to distant Scotland, with a different language, climate, and manners to their own. It is, however, their very poverty which first propelled Italians there, although latterly their business is so widely and solidly established that Scotland draws to itself Italians of the hardworking, but by no means impecunious class. While well-to-do Italians seldom visit Scotland, working Italians emigrato there in large numbers, and apparently are quite satisfied with the financial results. They know that they go not mere'y to a wealthy country, but also to a people who have always regarded Italians is friends, and who enthusiastically admired Garibaldi-

"A name that earth will not forget

Till earth has roll'd her latest year." 1

1 Tennyson on Garibaldi, who planted a tree in the poet's garden. 